\title{
Peran Kadar Feritin Serum dan Vitamin D Terhadap Keterlambatan Usia Tulang pada Anak Penyandang Talasemia Beta Mayor
}

Karla Roshinta Rachel Napitu, Tetty Yuniati, Ponpon Idjradinata

Departemen Ilmu Kesehatan Anak Fakultas Kedokteran Universitas Padjadjaran/ Rumah Sakit Hasan Sadikin, Bandung

Latar belakang. Anak penyandang talasemia beta mayor sering mengalami komplikasi kelainan tulang berupa gangguan maturasi tulang. Iron overload akibat transfusi darah berulang diketahui berkontribusi atas gangguan ini. Kadar vitamin D yang rendah juga sering ditemukan pada pasien talasemia beta mayor.

Tujuan. Untuk mengetahui peranan kadar feritin serum dan vitamin D terhadap keterlambatan usia tulang.

Metode. Observasi analitik korelasional rancangan potong lintang, pada anak usia 3-18 tahun dengan talasemia beta mayor. Dilakukan pemeriksaan kadar feritin serum, vitamin D, dan usia tulang. Analisis multi variabel menggunakan regresi linier ganda. Hasil uji bermakna bila nilai $\mathrm{p}<0,05$.

Hasil. Subjek sebanyak 50 anak. Rerata kadar feritin serum dan vitamin D yaitu $3092 \mathrm{ng} / \mathrm{mL}$ dan $26 \mathrm{ng} / \mathrm{mL}$. Usia tulang defisit pada $39(78 \%)$ subjek. Persamaan regresi ganda defisit usia tulang (bulan) yaitu 32,872-25,675*log (kadar vitamin D) + 0,007*kadar feritin serum sedangkan regresi multipel linier yaitu 51\%. Kadar feritin serum diatas $2610 \mathrm{ng} / \mathrm{mL}$ dapat memprediksi defisit usia tulang > 12 bulan.

Kesimpulan. Korelasi positif kuat antara kadar feritin serum terhadap keterlambatan usia tulang $(\mathrm{p}<0,001 ; \mathrm{r}=0,7)$ dan korelasi negatif lemah antara vitamin D terhadap keterlambatan usia tulang $(\mathrm{p}=0,02 ; \mathrm{r}=-0,3)$. Peranan feritin dan vitamin $\mathrm{D}$ terhadap keterlambatan usia tulang, yaitu sebesar 51\%. Sari Pediatri 2020;22(4):224-9

Kata kunci: feritin, vitamin D, talasemia beta mayor

\section{The Role of Serum Ferritin and Vitamin D Levels on Delay in Bone Age in Children with Beta Major Thalassemia}

Karla Roshinta Rachel Napitu, Tetty Yuniati, Ponpon Idjradinata

Background. Children with beta thalassemia major often experience complications of bone maturation disorders. Iron overload due to repeated blood transfusions is known to contribute to these disorders. Low vitamin D level is also commonly found in patients with beta thalassemia major.

Objective. To determine the role of serum ferritin and vitamin D levels in bone age delays.

Methods. This is a correlational analytic observation with cross-sectional designs, in children aged 3-18 years with beta thalassemia major. Serum ferritin levels, vitamin D, and bone age were examined. Multivariate analysis using multiple linear regression. The significance value of $\mathrm{p}<0.05$.

Results. The subjects were 50 children. Mean serum ferritin and vitamin D level were $3092 \mathrm{ng} / \mathrm{mL}$ and $26 \mathrm{ng} / \mathrm{mL}$ respectively. Bone age was delays in $39(78 \%)$ subjects. Multiple regression equation for bone age delay (month) is $32.887-25.675 * \log$ (vitamin $\mathrm{D}$ level $)+0.007^{*}$ serum ferritin level while linear regression is $51 \%$. Serum ferritin levels above $2610 \mathrm{ng} / \mathrm{mL}$ can predict bone age delay $>12$ months.

Conclusions. The strong positive correlation between serum ferritin level and bone age delay $(\mathrm{p}<0.001 ; \mathrm{r}=0.7)$ and a weak negative correlation between vitamin $\mathrm{D}$ level and bone age delay $(\mathrm{p}<0.001 ; \mathrm{r}=0.7)$. The role of ferritin and vitamin $\mathrm{D}$ levels to bone age delay was 51\%. Sari Pediatri 2020;22(4):224-9

Keyword: ferritin, vitamin D, mayor thallasemia

Alamat korespondensi: Karla Roshinta Rachel Napitu. Departemen Ilmu Kesehatan Anak Fakultas Kedokteran Universitas Padjadjaran/ Rumah Sakit Hasan Sadikin, Bandung. Email: karlashinta@gmail.com 
A nak penyandang talasemia beta mayor sering mengalami komplikasi kelainan tulang yang dikenal dengan sebutan Thalassemia Bone Disease (TBD). ${ }^{1}$ Kelebihan besi atau iron overload akibat transfusi darah berulang diketahui berkontribusi terhadap gangguan ini dengan menghambat proses pembentukan tulang dan meningkatkan resorpsi tulang. ${ }^{2}$ Feritin merupakan protein intraselular yang menyimpan besi didalam tubuh. Peningkatan kadar feritin serum dapat memprediksi kelebihan besi akibat transfusi darah berulang pada talasemia beta mayor, sehingga dapat digunakan sebagai penanda/marker peningkatan besi. ${ }^{3}$ Menentukan usia tulang pada anak penyandang talasemia beta mayor juga menjadi hal yang penting karena dapat mengetahui apakah komplikasi terhadap sistem skeletal telah terjadi. ${ }^{4}$

Vitamin D berperan penting pada homeostasis kalsium, metabolisme dan mineralisasi tulang. ${ }^{5} 25$ dihydroxyvitamin D $(1,25$ (OH Untuk mencapai masa tulang yang normal dan mencegah risiko fraktur pada pasien talasemia dibutuhkan kadar vitamin D yang optimal di dalam serum. ${ }^{6}$ Toksisitas besi di hati menyebabkan terganggunya proses hidroksilasi vitamin D. ${ }^{7}$

Penelitian ini bertujuan untuk mengetahui peranan kadar feritin serum dan vitamin D terhadap terjadinya keterlambatan usia tulang pada anak penyandang talasemia beta mayor.

\section{Metode}

Bentuk penelitian adalah potong lintang dengan pemilihan sampel secara consecutive sampling. Penelitian dilaksanakan pada bulan Juli - Oktober 2019 di klinik talasemia anak RSUP Hasan Sadikin, Bandung. Kriteria inklusi adalah 1) anak usia 3-18 tahun yang sudah didiagnosis talasemia beta mayor, 2) kadar feritin serum $>500 \mathrm{ng} / \mathrm{mL}, 3$ ) tidak menderita penyakit infeksi akut ataupun kronis, seperti tuberkulosis, tidak memiliki suatu sindrom tertentu, seperti Turner syndrome, Edward syndrome, tidak mempunyai kelainan jantung bawaan, ataupun kelainan ginjal, 4). status gizi baik, dan 5) rekam medis pasien lengkap berisi informasi tentang usia, jenis kelamin, hasil pemeriksaan laboratorium rutin, berat badan, tinggi badan, lingkar lengan atas, riwayat kelasi besi, usia pertama kali terdiagnosis, dan durasi/rentang waktu transfusi packed red cell. Penelitian ini telah memperoleh kelayakan etik dari Komite Etik Rumah Sakit Dr. Hasan Sadikin dan ijin penelitian dengan nomor LB.02.01/X.2.2.1/11194/2019.

Orangtua subjek yang memenuhi kriteria inklusi diberikan penjelasan dan mengisi informed consent. Subjek kemudian diperiksa kadar feritin dan vitamin D di laboratorium patologi klinik RSHS serta pemeriksaan usia tulang di bagian radiologi RSHS. Pemeriksaan kadar feritin serum menggunakan metode enhanced chemiluminescence immunoassay (ECLIA). Pemeriksaan vitamin D dengan mengukur kadar 25(OH) D serum menggunakan metode enzymelinked immunosorbent assay (ELISA). Kriteria defisiensi vitamin D bila kadar $25(\mathrm{OH}) \mathrm{D}<20 \mathrm{ng} /$ $\mathrm{mL}$, insufisiensi bila kadar 20-30 ng/mL, sedangkan normal bila kadar $>30 \mathrm{ng} / \mathrm{mL}$. Pemeriksaan usia tulang dengan menggunakan metode Greulich-Pyle.

Analisis data meliputi univariabel, bivariabel dan multivariabel. Uji normalitas data dengan uji Shapiro-Wilk. Distribusi data normal jika nilai $\mathrm{p}>0,05$. Analisis bivariabel menggunakan korelasi Pearson untuk data yang berdistribusi normal, sedangkan data yang tidak terdistribusi normal menggunakan korelasi rank Spearman. Interpretasi besarnya koefisien korelasi berdasarkan kriteria Guilford, yaitu $0,0-<0,2$ = sangat lemah; $0,2-0,4=$ lemah; $0,4-<0,7=$ sedang, $0,7-<0,9=$ kuat, $0,9-1,0=$ sangat kuat. Arah korelasi positif searah berarti semakin besar nilai satu variabel, semakin besar pula nilai variabel lainnya. Arah korelasi negatif berlawanan arah berarti semakin besar nilai satu variabel, semakin kecil nilai variabel lainnya. Analisis data dengan program statistical product and service solution (SPSS) for windows versi 18.0, kemaknaan hasil uji bila nilai $\mathrm{P} \leq 0,05$.

\section{Hasil}

Jumlah subjek yang mememenuhi kriteria inklusi sebanyak 50. Karakteristik subjek penelitian mencakup jenis kelamin, usia kronologis, defisit usia tulang, kadar vitamin D dan kadar feritin serum tertera pada Tabel 1 .

Pada Tabel 1 karakteristik subjek perbandingan antara lelaki dan perempuan sama banyak. Kadar vitamin D rendah pada $66 \%$ subjek dengan perincian insufisiensi $40 \%$ dan defisiensi 26\%. Kadar feritin 
Tabel .1 Jumlah dan persentase jenis kelamin, usia kronologis, defisit usia tulang, kadar vitamin D, dan kadar feritin serum

\begin{tabular}{lcc}
\hline Karakteristik & Jumlah & $\%$ \\
\hline Jenis kelamin & & \\
$\quad$ Lelaki & 25 & 50 \\
Perempuan & 25 & 50 \\
Usia kronologis (bulan): & 4 & 8 \\
$\quad \leq 60$ & 10 & 20 \\
$61-120$ & 36 & 72 \\
$121-216$ & & \\
Kadar vitamin D (ng/mL) & 17 & 34 \\
Normal (>30) & 20 & 40 \\
Insufisiensi (20-30) & 13 & 26 \\
Defisiensi (<20) & & 2 \\
Feritin serum (ng/mL) & 1 & 28 \\
$<1000$ & 14 & 26 \\
$<2000$ & 13 & 20 \\
$2000-<3000$ & 10 & 4 \\
3000-<4000 & 2 & 20 \\
$4000-<5000$ & 10 & 22 \\
$\geq 5000$ & & 78 \\
Defisit usia tulang (bulan) : & 11 & \\
Tidak defisit & 39 & \\
Defisit & &
\end{tabular}

Tabel 2. Uji normalitas data feritin serum, vitamin D, usia kronologis dan defisit usia tulang

\begin{tabular}{|c|c|c|c|c|}
\hline \multirow[b]{2}{*}{ Variabel } & \multicolumn{3}{|c|}{ Ukuran statistik } & \multirow[b]{2}{*}{$\begin{array}{l}\text { Uji normalitas data } \\
\left.\text { (Nilai } \mathrm{p}^{*}\right)\end{array}$} \\
\hline & Rerata (SD) & Median & Rentang & \\
\hline Feritin serum & 3091,7 & 2614,6 & 936,3 & $<0,001$ \\
\hline Vitamin D & $26,62(10,77)$ & 26,06 & $6,06-58,42$ & 0,321 \\
\hline Usia kronologis (bulan) & $137,9(47,0)$ & 142 & $48-214$ & 0,028 \\
\hline Defisit usia tulang (bulan) & $18,34(18,64)$ & 12 & $0-76$ & $<0,001$ \\
\hline
\end{tabular}

Keterangan : $\left.{ }^{*}\right)$ berdasarkan uji Shapiro-Wilk. Data berdistribusi normal jika p $>0,05$.

Tabel 3. Korelasi antara defisit usia tulang dengan kadar feritin serum dan vitamin D

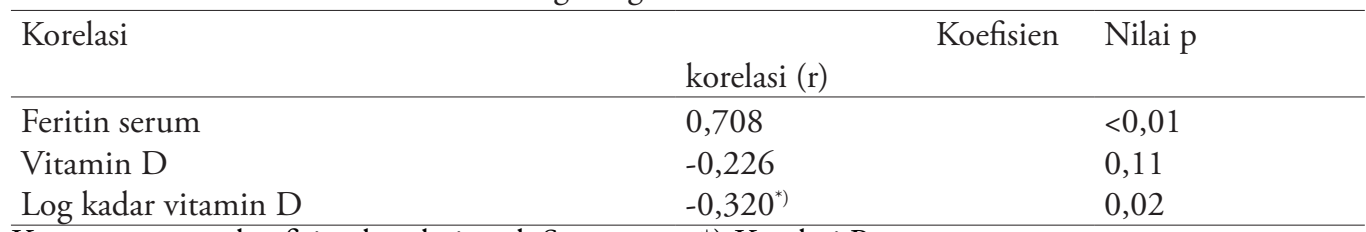

Keterangan : $r=$ koefisien korelasi rank Spearman $\left.;{ }^{*}\right)$ Korelasi Pearson 
Karla Roshinta Rachel Napitu dkk: Peran kadar feritin serum dan vitamin D terhadap keterlambatan usia tulang pada talasemia beta mayor

Tabel 4. Korelasi antara defisit usia tulang dengan kadar vitamin D, feritin serum, usia kronologis, dan jenis kelamin

\begin{tabular}{lcccc}
\hline Variabel & Koef B & SE (B) & Nilai t & Nilai p \\
\hline Model awal & & & & \\
$\quad$ Log (kadar vitamin D) & $-29,980$ & 12,678 & $-2,365$ & 0,022 \\
Kadar feritin serum & 0,007 & 0,001 & 6,120 & $<0,001$ \\
$\quad$ Usia kronologis & $-0,017$ & 0,050 & $-0,344$ & 0,732 \\
$\quad$ Jenis kelamin & $-1,696$ & 4,407 & $-0,385$ & 0,702 \\
II. Model akhir & & & & \\
Log (kadar vitamin D) & $-25,675$ & 9,860 & $-2,604$ & 0,012 \\
Kadar feritin serum & 0,007 & 0,001 & 6,231 & $<0,001$ \\
$\quad$ Konstanta & 32,872 & - & - & - \\
\hline
\end{tabular}

Keterangan : Untuk model akhir $\mathrm{F}=24,302 ; \mathrm{p}<0,001$ dengan $\mathrm{R}^{2}$ multipel $=51 \%$.

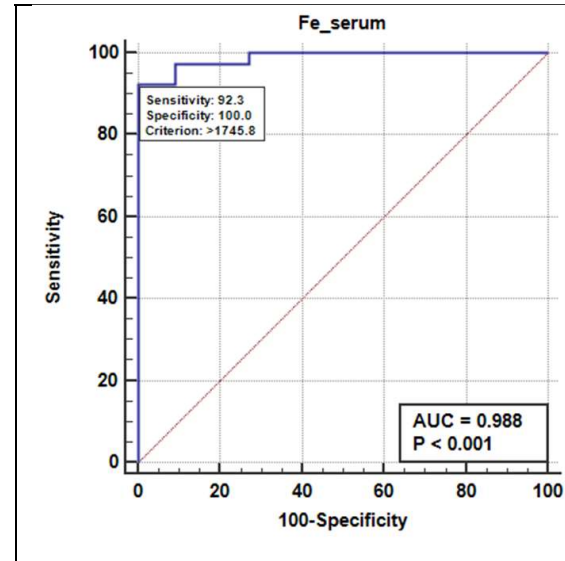

(a)

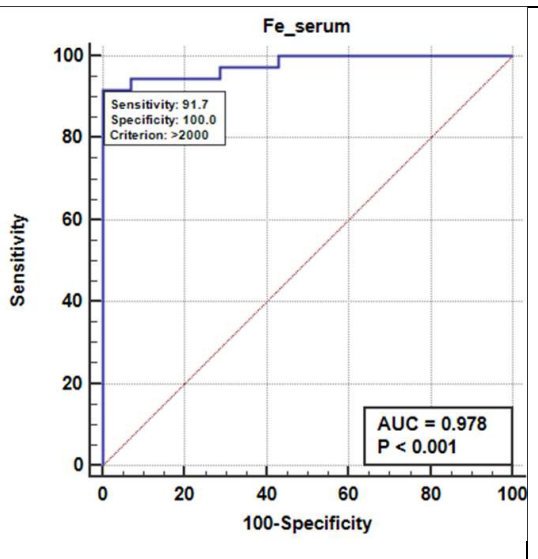

(b)

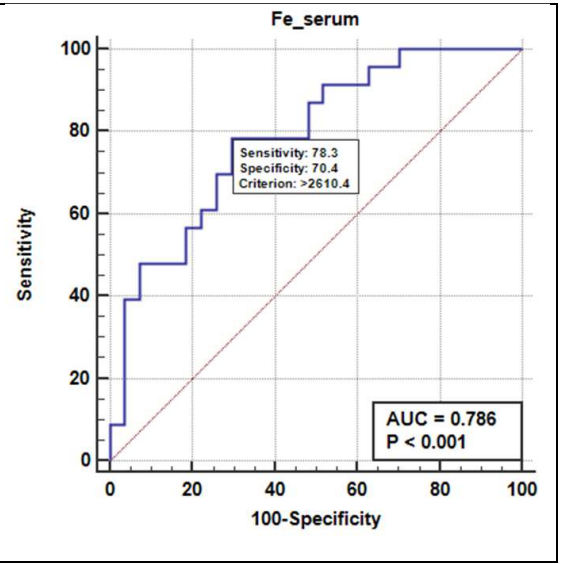

(c)

Gambar 3. Kurva receiving operating characteristic (ROC) untuk nilai cut off point kadar feritin serum dalam memprediksi defisit usia tulang (a) defisit usia tulang 0-6 bulan; (b) defisit usia tulang 6-12 bulan; (c) defisit usia tulang >12 bulan.

serum secara umum $>1000 \mathrm{ng} / \mathrm{mL}$ dan usia tulang sudah mengalami defisit pada $78 \%$ subjek. Pada Tabel 2 tampak bahwa hanya kadar vitamin D yang tidak terdistribusi normal. Terdapat korelasi negatif yang kuat antara feritin serum dengan defisit usia tulang $(\mathrm{r}=0,7 ; \mathrm{p}<0,01)$ dan korelasi negatif antara kadar vitamin $\mathrm{D}$ dengan defisit usia tulang $(\mathrm{r}=-0,3 ; \mathrm{p}=0,02)$. (Tabel 3).

Pada Tabel 4 dilakukan analisis regresi linier peran kedua variabel terhadap defisit tulang, yaitu sebesar $51 \%$, sedangkan persamaan regresi ganda yang didapat yaitu, defisit usia tulang (bulan) $=32,872-25,675^{*}$ $\log$ (kadar Vit D) +0,007*kadar feritin serum.

Tertera pada Gambar 3 (a), kadar feritin serum $>1746 \mathrm{ng} / \mathrm{mL}$ dapat memprediksi defisit usia tulang sebanyak $0-6$ bulan $(\mathrm{p}=<0,001$; sensitifitas 92,31 ; spesifisitas $100 \%$ ), Gambar 3 (b) $>2000 \mathrm{ng} / \mathrm{mL}$ sebanyak 6-12 bulan ( $\mathrm{p}=<0,001$; sensitifitas 91,67 ; spesifisitas $100 \%$ ), dan Gambar 3 (c) $>2610 \mathrm{ng} / \mathrm{mL}$ sebanyak $>12$ bulan $(\mathrm{p}=<0,001$; sensitifitas 78,26 ; spesifisitas 70,37\%).

\section{Pembahasan}

Transfusi darah secara rutin pada pasien talasemia mayor, selain sebagai terapi utama juga mengakibatkan terjadinya penumpukan besi di berbagai organ (hemosiderosis). Terdapat besi bebas yang tidak terikat 
pada transferin, feritin, ataupun heme disebut non transferrin bounding iron (NTBI) atau labile plasma iron (LPI). Non transferrin binding iron melalui reaksi Fenton dapat mengatalisis pembentukan senyawa yang sangat toksik, yaitu hidroksi radikal bebas (radikal $\mathrm{OH}$ ), menghasilkan stres oksidatif dan kerusakan mitokondria, lisosom, membran lipid, protein, DNA hingga kematian sel. ${ }^{11}$ Hemosiderosis pada tulang, hepar, dan organ endokrin dapat menyebabkan gangguan metabolisme tulang. ${ }^{10}$ Pada studi in vitro didapatkan bahwa besi bebas menghambat aktivitas osteoblast dan meningkatkan diferensiasi osteoklas serta resorpsi tulang, melalui peningkatan aktivator reseptor nuclear factor $\kappa B$ ligand / receptor actifator of nuclear factor ${ }_{K} B$ ligand (NF-KB/RANKL) hingga osteoprotegerin (OPG). Kelainan tulang yang terjadi dapat berupa perawakan pendek, osteoporosis, penurunan densitas tulang, terlambatnya usia tulang hingga fraktur. Pada anak dengan talasemia beta mayor, usia tulang yang terlambat merepresentasikan gangguan pertumbuhan dan metabolisme tulang.

Tigapuluh sembilan (78\%) subjek mengalami keterlambatan usia tulang yang bervariasi, mulai dari 5 bulan hingga 76 bulan. Sebelas (22\%) subjek usia tulang masih normal. Hal tersebut dipengaruhi oleh kepatuhan mengonsumsi kelasi besi, kecukupan asupan kalsium, kadar vitamin D yang optimal, ataupun faktor lain yang tidak diteliti pada penelitian ini. Hasil ini sesuai dengan penelitian terbaru tentang perbandingan usia tulang dan usia kronologis pada pasien talasemia yang dilakukan oleh Imtiaz dkk. ${ }^{12}$ Penelitian Imtiaz melaporkan bahwa usia tulang ditemukan suboptimal seiring dengan pertambahan usia kronologis pasien talasemia mayor di usia anak dan remaja.

Kami menemukan korelasi yang kuat antara kadar feritin serum terhadap defisit usia tulang. Semakin tinggi kadar feritin serum maka semakin besar defisit usia tulang yang terjadi. Pada gambar 3 kadar feritin serum >1746 ng/mL dapat memprediksi defisit usia tulang sebanyak 0-6 bulan, dan meningkat menjadi 6-12 bulan pada kadar feritin $>2000 \mathrm{ng} / \mathrm{mL}$, sedangkan kadar feritin $>2610 \mathrm{ng} / \mathrm{mL}$ keterlambatan usia tulang $>12$ bulan. Hal ini sesuai dengan penelitian oleh Andayani $\mathrm{dkk}^{14}$ yang melaporkan adanya defisit usia tulang sebesar $\leq 36$ bulan pada kadar feritin serum $<5000 \mathrm{ng} / \mathrm{dL}$ dan defisit usia tulang sebesar $\geq 36$ bulan pada kadar feritin serum $5000 \mathrm{ng} / \mathrm{dL}$.

Pengaruh feritin serum dan vitamin $D$ terhadap defisit usia tulang sebesar 51\%, sedangkan sisanya $49 \%$ dipengaruhi variabel lain yang tidak diteliti. Perkiraan besar defisit usia tulang (bulan) yaitu 32,872 - 25,675* $\log ($ kadar Vit D) + 0,007*kadar feritin serum. Kadar vitamin D yang rendah didapatkan pada 66\% subjek terbagi dalam kategori insufisiensi sebanyak $20(40 \%)$ dan defisiensi 13 (26\%). Hasil ini serupa dengan penelitian Gombar $\mathrm{dkk}^{7}$ yang melaporkan kadar vitamin $\mathrm{D}$ rendah secara bermakna pada pasien talasemia dibandingkan dengan populasi normal.

Penelitian lain oleh Bajoria dkk, ${ }^{10}$ pasien talasemia beta mayor mempunyai risiko delapan kali mempunyai kadar vitamin D yang rendah dibanding anak normal. Kami menemukan hubungan kadar vitamin D dengan defisit usia tulang, yaitu semakin tinggi kadar vitamin $\mathrm{D}$, semakin kecil defisit usia tulang yang terjadi. Demikian pula sebaliknya, semakin rendah kadar vitamin D semakin besar defisit usia tulang. Hasil penelitian ini sesuai dengan penelitian oleh Shah $\mathrm{dkk}^{13}$ yang melaporkan bahwa kadar vitamin $\mathrm{D}<30 \mathrm{ng} / \mathrm{mL}$ berhubungan dengan defisit usia tulang $>36$ bulan.

\section{Kesimpulan}

Terdapat korelasi positif kuat antara kadar feritin serum terhadap keterlambatan usia tulang, sedangkan kadar vitamin D berkorelasi negatif lemah dengan keterlambatan usia tulang. Dengan demikian kadar feritin dan vitamin $\mathrm{D}$ berperan dalam terjadinya keterlambatan usia tulang.

\section{Daftar pustaka}

1. Wong P, Fuller PJ, Gillespie MT, Milat F. Bone disease in thalassemia: A molecular and clinical overview. Endocr Rev 2016;37:320-46.

2. Steer K, Stavnichuk M, Morris M, Komarova S V. Bone Health in Patients With Hematopoietic Disorders of Bone Marrow Origin: Systematic Review and Meta- Analysis. J Bone Miner Res 2017;32:731-42.

3. Creo AL, Schwenk WF. Bone age: A handy tool for pediatric providers. Pediatrics 2017;140:e20171486. doi:10.1542/ peds.2017-1486.

4. Asif M, Manzoor Z, Farooq M, dkk. Correlation between serum ferritin level and liver function tests in thalassemic patients receiving multiple blood transfusions. Int J Res Med Sci 2014;2:988.

5. Bikle DD. Vitamin D and bone. Dalam: Watson RR, Mahadevan D, penyunting. Handbook of nutrition and diet 
in therapy of bone diseases. Edisi ke-13. Wageningen Academic Publishers; 2016.h.211-32.

6. Napoli N, Strollo R, Sprini D, Maddaloni E, Rini GB, Carmina E. Serum 25-OH vitamin D in relation to bone mineral density and bone turnover. Int J Endocrinol 2014; 2014:487463. doi:10.1155/2014/487463.

7. Gombar S, Parihar K, Choudhary M. Comparative study of serum ferritin and vitamin $\mathrm{D}$ in thalassemia patients with healthy controls. Int J Res Med Sci 2018;6:693.

8. Tzoulis P, Ang AL, Shah FT, dkk. Prevalence of low bone mass and vitamin d deficiency in $\beta$-thalassemia major. Hemoglobin 2014;38:173-8.

9. Soliman A, De Sanctis V, Yassin M. Vitamin D status in thalassemia major: An update. Mediterr J Hematol Infect Dis 2013;5:e2013057. doi:10.4084/MJHID.2013.057.

10. Bajoria R, Rekhi E, Almusawy M, Chatterjee R. Hepatic Hemosiderosis Contributes to Abnormal Vitamin D-PTH
Axis in Thalassemia Major. J Pediatr Hematol Oncol 2019;41:E83-9.

11. Sewwandi Karunaratna AMD, Ranasingha JS, Mudiyanse RM. Iron overload in beta thalassemia major patients. Int J Blood Transfus Immunohematol 2017;7:33.

12. Imtiaz H, Akbar W, Jadoon OK, Ali U, Ambreen S, Javed S, dkk. A Comparison Of Skeletal Age Of Thalassaemic Patients Of 9-15 Years With Chronological Age By Radiography. J Ayub Med Coll Abbottabad 2018;30:S642-6.

13. Shah B, Gosai D, Shah H. Study of vitamin D status and bone age in children with Thalassemia major. Int J Med Sci Clin Invent. 2017;4:2639. doi:https://doi.org/10.18535/ ijmsci/v4i2.01.

14. Andayani SH, Sekarwana N, Fadil R. Association between age and serum ferritin level with bone age deficit in children with thalassemia major. Paediatr Indones 2008;48:33-6. 